\title{
Description of a hepatopancreatic rickettsia-like organism in the redclaw crayfish Cherax quadricarinatus
}

\author{
Brett F. Edgerton ${ }^{1, *}$, Howard C. Prior ${ }^{2}$ \\ ${ }^{1}$ Department of Microbiology and Immunology, James Cook University, Townsville, Queensland 4810, Australia \\ ${ }^{2}$ Animal Research Institute, Queensland Department of Primary Industries, 665 Fairfield Rd, Yeerongpilly, \\ Queensland 4105, Australia
}

\begin{abstract}
Basophilic, Gram-negative, microcolonies of rickettsia-like organisms were observed in the hepatopancreatic tubule epithelium of 1 moribund Cherax quadricarinatus from a farm in north Queensland. The tissue tropism of the organism is distinct from the systemic rickettsia-like organism previously described from $C$. quadricarinatus. This paper briefly describes the histopathology, cytopathology and basic morphology of the hepatopancreatic rickettsia-like organism
\end{abstract}

KEY WORDS: Cherax quadricarinatus $\cdot$ Redclaw freshwater crayfish · Rickettsia-like organism - Disease Pathology

Rickettsia-like organisms (RLO) infect a range of aquatic crustaceans including amphipods, crabs, prawns and freshwater crayfish (Federici et al. 1974, Bonami \& Pappalardo 1980, Johnson 1984, Sparks et al. 1985, Brock et al. 1986, Anderson et al. 1987, Krol et al. 1991, Ketterer et al. 1992, Owens et al. 1992, Bower et al. 1996). The decapod-infecting RLOs are either confined to the hepatopancreatic tubule epithelium, or are systemic. The systemic RLOs never have been observed to infect endodermal enteric tissues. The RLO infecting the redclaw freshwater crayfish Cherax quadricarinatus, and originally described by Ketterer et al. (1992) and Owens et al. (1992), is in the systemic category. A RLO was observed exclusively in the hepatopancreatic tubule epithelium of one moribund C. quadricarinatus during an investigation of chronic low-grade mortality at a farm in north Queensland. Histopathology, cytopathology and basic morphology of this organism are reported here.

\footnotetext{
- Present address: Animal Quarantine Policy Branch, Australian Quarantine and Inspection Service, GPO Box 858, Canberra, ACT 2601, Australia.

E-mail: brett.edgerton@aqis.gov.au
}

Materials and methods. The moribund Cherax quadricarinatus was collected from a pond bank at a farm in north Queensland during an investigation of chronic crayfish mortality (Edgerton et al. 1995). The crayfish was sacrificed and fixed immediately in Bouin's fixative (Drury \& Wallington 1967). Dissected tissues were processed routinely for histology including haematoxylin and eosin staining of sections. Special stains (Culling et al. 1985) included Brown and Brenn Gram, phloxine and tartrazine, and Periodic Acid Schiff (PAS).

Unstained, $5 \mu \mathrm{m}$ thick sections of paraffin embedded tissues were processed for electron microscopy by a method adapted from Bhatnagar et al. (1977). Briefly, lesions were located on the paraffin section. Excess tissue was removed, and the remainder was deparaffinised, rehydrated, refixed in glutaraldehyde, postfixed in osmium tetroxide and dehydrated in a graduated acetone series. Infiltration with increasing concentrations of Spurr's resin was carried out on the slide, using a short section cut from a plastic pipette to create a dam of resin over the section. After overnight polymerisation at $60^{\circ} \mathrm{C}$ the plastic dam was cut away, the slide gently warmed and the resin stub with attached section eased off the glass slide. Ultrathin sections stained with uranyl acetate and lead citrate were examined with a Philips CM 10 TEM.

Results. Basophilic inclusions were observed in the cytoplasm of hepatopancreatocytes in adjacent tubules. Nearly all hepatopancreatocytes in cross-sectioned tubules contained the inclusions (Fig. 1). The inclusions were Gram-negative, moderately PAS positive, intensely phloxophilic, and often had a clear central zone containing faint eosinophilic material. Intracytoplasmic, Gram-negative microcolonies were not observed in any other tissues. Sectioning for special stains went beyond the focus of infection, and the 


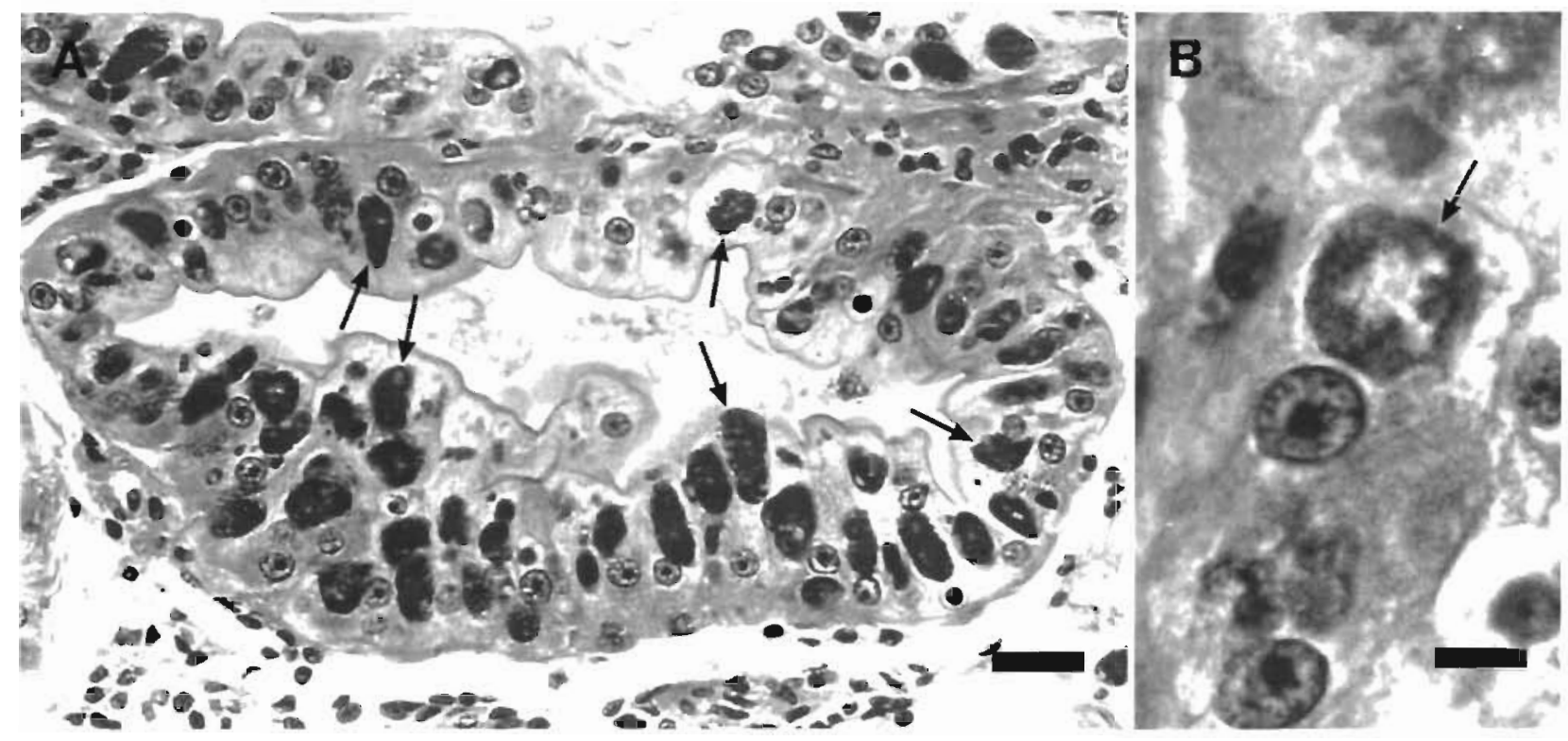

Fig. 1. Light micrographs of basophilic, Gram-negative inclusions (arrows) in the cytoplasm of hepatopancreatocytes in Cherax quadricarinatus H\&E. (A) Almost all hepatopancreatocytes in the tubules are infected. Scale bar $=42 \mu \mathrm{m}$. (B) Inclusions often contain cleared areas. Scale bar $=10 \mu \mathrm{m}$

lesions were not observed in the remaining hepatopancreatic tissues stored in Bouin's fixative. The crayfish also had early stage eye necrosis (Edgerton et al. 1995), bacteraemia, and moderate Cherax quadricarinatus bacilliform virus infection.

Electron microscopy indicated that the cytoplasmic inclusions were microcolonies of a RLO within membrane-bounded vacuoles (Fig. 2). The RLO had both a cell wall and plasma membrane and was pleomorphic, with rounded forms more common than rod-shaped forms. The RLO ranged in length from 0.2 to $0.4 \mu \mathrm{m}$ but further morphological and cytopathological descriptions were not possible due to suboptimal fixation for electron microscopy.

Discussion. The basophilic inclusions were similar to rickettsia-like microcolonies which have been observed systemically in Cherax quadricarinatus (Ketterer et al. 1992, Owens et al. 1992), and which were observed in approximately one third of moribund crayfish examined in the study of the chronic mortality at this farm (Edgerton et al. 1995, Edgerton 1996). The same, or very similar, systemic RLO has been associated with mortality in $C$. quadricarinatus farms in Ecuador (Jiménez \& Romero 1997). The systemic RLO infects the spongy connective tissues, neural tissues, nephridial canal epithelium, myocardium, cuticular epithelium, haemopoietic and mandibular organ cells (Edgerton 1996). The systemic RLO in C. quadricarinatus has never been observed in endodermal enteric tissues even in very intense fulminating infections (Edgerton et al. 1995, Edgerton 1996, unpubl. data). In this report the RLO was observed only in hepatopancreatocytes. This distinct differentiation of tissue tropism is consistent with other crustacean-infecting RLOs (Bower et al. 1996). Furthermore, the cytopathology also differed in that the systemic rickettsia-like microcolonies do not usually contain central clear zones as was observed with this hepatopancreatic RLO. It therefore appears that at least 2 distinct RLOs infect $C$. quadricarinatus; one a systemic agent, and the other exclusively infecting hepatopancreatocytes.

The fact that the hepatopancreatic RLO has been observed in only 1 Cherax quadricarinatus may suggest that it is relatively rare. Farming of C. quadricarinatus commenced approximately 10 yr ago in Australia and the industry is still in its infancy. C. quadricarinatus aquaculture in Australia is unsophisticated, and many farmers are hobbyists. Low numbers of sick crayfish are detected by most farmers, but are not reported as they are considered to be normal or insignificant. Survival as low as $30 \%$ is not uncommon in some ponds without obvious explanation; however, disease is rarely considered as the cause. Research on disease remains a low priority as there have not been major widespread epizootics reported in the industry to this point. Edgerton (1996) conducted histopathological surveys on farmed C. quadricarinatus in north Queensland to determine the prevalence of potential pathogens. However, the examination of 32 moribund crayfish during the chronic mortality which occurred at one of the surveyed farms (Edgerton et al. 1995, Edgerton 1996) revealed a high incidence for some pathogens 

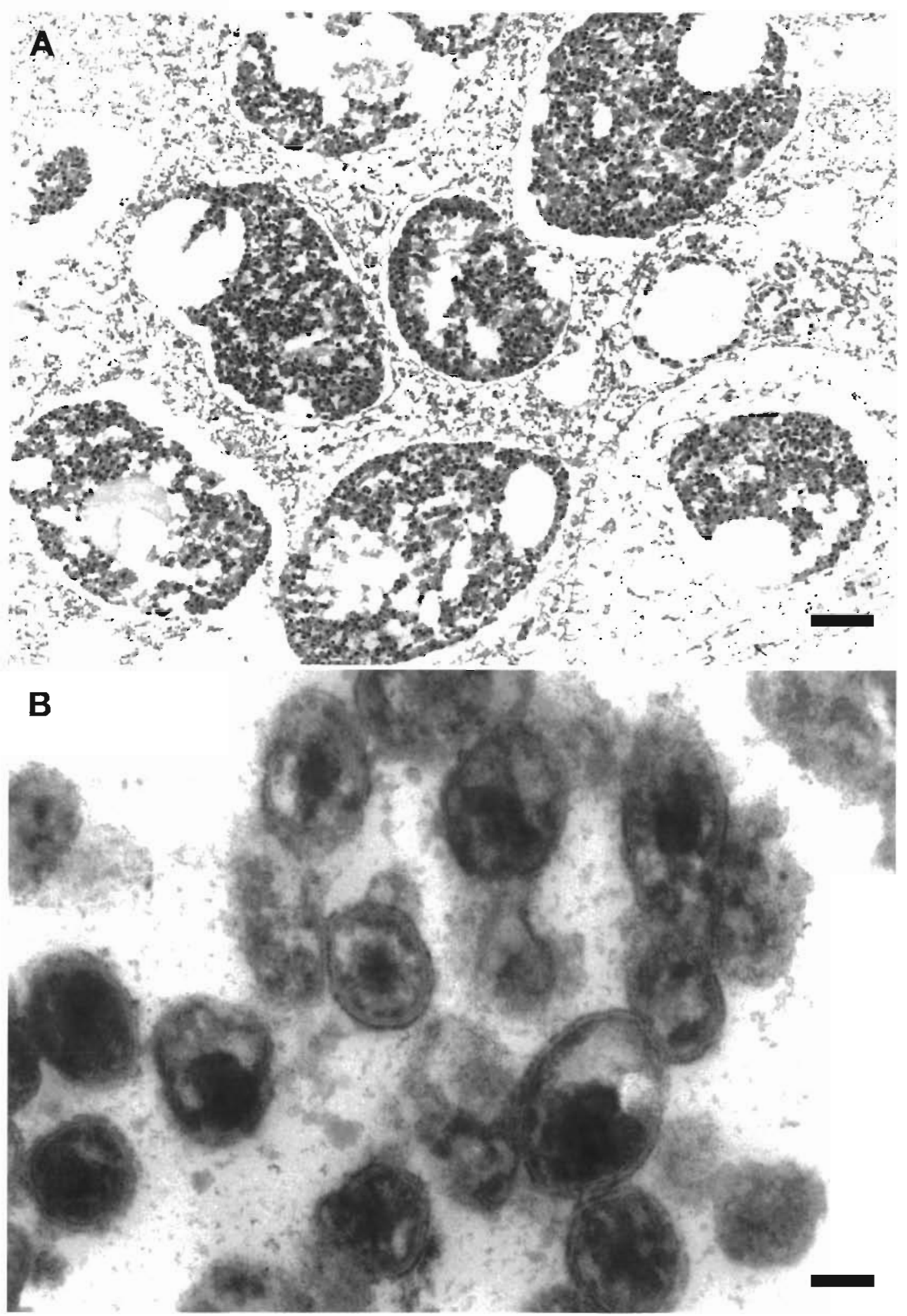

Fig. 2. Electron micrographs of rickettsia-like microorganisms in Cherax quadricarinatus hepatopancreatocytes. Uranyl acetate and lead citrate. (A) Several rickettsia-like microcolonies in cytoplasmic vacuoles. Scale bar $=3 \mu \mathrm{m}$. (B) Rickettsia-like microorganisms had both a cell wall and a plasma membrane and were pleomorphic, with rounded forms most common. Scale bar $=128 \mathrm{~nm}$ 
which were not detected in the survey, such as the systemic RLO. Closer surveillance of ponds, and submission of sick animals for disease diagnosis, will improve knowledge of diseases in cultured C. quadricarinatus. To this point, there have been insufficient studies done to determine the full significance of pathogens in C. quadricarinatus aquaculture, and further studies may show that the hepatopancreatic RLO is more common than these initial studies suggest.

Acknowledgements. This research was partly funded by an Australian Research Council grant (A19332302), and was partly conducted during a $\mathrm{PhD}$ research programme by B.F.E. which was supervised by Dr Leigh Owens (Department of Microbiology and Immunology, James Cook University). Thanks to Laurie Reilly (James Cook University) and Elizabeth Kulpa (Oonoonba Veterinary Laboratory, Queensland Department of Primary Industries) for histological preparations.

\section{LITERATURE CITED}

Anderson IG, Shariff M, Nash G, Nash M (1987) Mortalities of juvenile shrimp, Penaeus monodon, associated with Penaeus monodon baculovirus, cytoplasmic reo-like virus, and rickettsial and bacterial infections, from Malaysian brackishwater ponds. Asian Fish Sci 1:47--64

Bhatnagar R, Johnson GR, Christian RG (1977) Electron microscopy for rapid identification of animal viruses in hematoxylin-eosin sections. Can J Comp Med 41:416-419

Bonami JR, Pappalardo R (1980) Rickettsial infection in marine crustacea. Experientia 36:180-181

Bower SM, Meyer GR, Boutillier JA (1996) Stained prawn disease (SPD) of Pandalus platyceros in British Columbia, Canada, caused by a rickettsial infection. Dis Aquat Org $24: 41-54$

Editorial responsibility: Tim Flegel,

Bangkok, Thailand
Brock JA, Nakagaw LK, Hayashi T, Teruya S, Van Campen $\mathrm{H}$ (1986) Hepatopancreatic rickettsial infection of the penaeid shrimp, Penaeus marginatus (Randall), from Hawaii. J Fish Dis 9:73-77

Culling CFA, Allison RT, Barr WT (1985) Cellular pathology techniques, 4th edn. Butterworths, London

Drury RAB, Wallington EA (1967) Carleton's histological technique. Oxford University Press, New York

Edgerton BF (1996) Viruses of freshwater crayfish. PhD thesis, Department of Biomedical and Tropical Veterinary Sciences, James Cook University, Townsville

Edgerton B, Owens L, Harris L, Thomas A, Wingfield M (1995) A health survey of farmed redclaw crayfish Cherax quadricarinatus (Von Martens), in tropical Australia. Freshw Crayfish 10:322-338

Federici BA, Hazard EI, Anthony DW (1974) Rickettsia-like organism causing disease in a crangonid amphipod from Florida. Appl Microbiol 28:885-886

Jiménez R, Romero X (1997) Infection by intracellular bacterium in red claw crayfish, Cherax quadricarinatus (Von Martens), in Ecuador. Aquac Res 28:923-929

Johnson PT (1984) A rickettsia of the blue king crab, Paralithodes platypus. J Invertebr Pathol 44:112-113

Ketterer PJ, Taylor DJ, Prior HC (1992) Systemic rickettsialike infection in farmed freshwater crayfish, Cherax quadricarinatus. In: Shariff M, Subasinghe RP, Arthur JR (eds) Diseases in Asian aquaculture I. Fish Health Section, Asian Fisheries Society, Manila, p 173-179

Krol RM, Hawkins WE, Overstreet RM (1991) Rickettsial and mollicute infections in hepatopancreatic cells of cultured Pacific white shrimp (Penaeus vannamer). J Invertebr Pathol 57:362-370

Owens L, Muir P, Sutton D, Wingfield M (1992) The pathology of microbial diseases in tropical Australian Crustacea. In: Shariff M, Subasinghe RP, Arthur JR (eds) Diseases in Asian aquaculture I. Fish Health Section, Asian Fisheries Society, Manila, p 165-172

Sparks AK, Morado JF, Hawkes JW (1985) A systemic microbial disease in the Dungeness crab, Cancer magister, caused by a Chlamydia-like organism. J Invertebr Pathol $45: 204-217$

Submitted: June 1, 1998; Accepted: December 16, 1998 proofs received from author(s): April 9, 1999 